\title{
UPTAKE OF METALS IN WILLOW BIOMASS PLANTATIONS FERTILISED WITH SEWAGE SLUDGE
}

\author{
Ingemar Lundström \\ Kenth Hasselgren \\ SWECO VIAK AB, Sweden
}

\begin{abstract}
Despite the main part of the sewage sludge (biosolids) production in Sweden meets the high quality requirements set up for recycling in agriculture, amounts of sludge spread to traditional crops are decreasing. This is mainly due to the negative attitude within the food industry to sludge use. However, sludge managers gradually develop other routes of sludge disposal.
\end{abstract}

For instance, sludge fertilisation of willow (Salix spp.) plantations for biofuel production has increased in recent years. The increase can be described by the fact that the willow farmers measure positive effects after sludge application and/or because willow is excluded from the food industry business.

The primary project objective is to clarify the practical extent of uptake of heavy metals in Salix wood through direct measurements of commercial willow plantations fertilised with biosolids. Some 20 plantations in Skåne and Örebro counties (south Sweden) were included in the investigation.

In general, uptake rates of metals in the Salix crop were high compared to traditional agricultural crops. Uptake of Cd in Salix stems was greatly exceeding (ca 10 times) the application of Cd with sludge (general sludge type and application rates), also including atmospheric deposition of $\mathrm{Cd}$. This means that a willow crop fertilised with sludge could work as a biological filter for remediation of Cd contaminated land. Uptake of $\mathrm{Zn}$ in Salix was fairly well balanced with the $\mathrm{Zn}$ application with sludge, whereas for other metals uptake in Salix wood was lower than the amount added with biosolids.

Sludge from the Swedish wastewater treatment plants can potentially supply the future willow-to-energy plantations (100 000's of hectares) in the country with full amounts of phosphorus and with parts of the other nutrient requirements. Further, application of biosolids increases the content of organic matter in the soil. 


\section{KEY WORDS:}

Biomass; Biosolids; Metals; Nutrients; Phytoremediation; Recycling; Salix; Sewage sludge; Short-rotation forestry; Wastewater; Willow.

\section{INTRODUCTION}

The Swedish quality requirements for sewage sludge recycling in agriculture are among the hardest in the world. Nevertheless, sludge in most places around Sweden is formally accepted for agricultural use. The high quality has been reached due to an effective and steady work with e.g. control of industrial wastewater connected to the sewerage and disconnection of polluted storm water and landfill leachate. In spite of this, the market is still negative to use sewage sludge in conventional farming, while utilisation of sewage sludge in short-rotation energy forestry (SREF) has a considerably higher acceptance. Today there are about 15000 ha of willow plantations in Sweden, out of which the majority are fertilised with sewage sludge. Almost $10 \%$ of the biosolids from the Swedish sewage treatment plants, corresponding to 100000 tons of dewatered biosolids with ca $20 \%$ dry solid content, is utilised annually in commercial willow biomass plantations (Alvén et al, 2003).

The main reasons why sludge is accepted in willow plantations are probably that:

- Willow is not included in the food production

- Existent routines for the care taking of sewage sludge can be kept.

- Sewage sludge replaces to large extents fertilisers, especially phosphorus, and increases the soil content of organic material.

- Sludge is spread on willow plantations during the spring, which decreases the risks for leaching of nutrients and gives a higher utilization of the resource compared to traditional use of sludge for agricultural use.

Different studies have shown that the willow crop is effective conceming accumulation of metals in the stem wood (e.g. Greger and Landberg, 1999; Bertholdsson, 2001; Hasselgren, 2003). This ability has been used at several places for remediation of polluted water and land.

The hypothesis of the study presented in this paper is that there are good possibilities to achieve a net removal of some metals via the harvest of stem wood and a sustainable accumulation of other metals. The prerequisite is that the application rate of sludge is balanced with plant need of phosphorus. Most studies are based on results from laboratory tests or small field tests where the metal aspect represents a small part of a major project. This study is focused on metal uptake in commercial energy forests fertilised with sewage sludge. 


\section{EXPERIMENTAL PROCEDURES}

About 20 commercial willow plantations in the south of Sweden were investigated during the winter 2002/2003 regarding the status of metals in soil and biomass. All of the plantations were historically fertilised with sewage sludge. The sludge application rate and content of metals in the sludge were known at most of the sites. A total of 140 hectares were included in the study.

The willow was planted between 1989 and 2000. Most of the plantations were established between 1990 and 1996 and had been harvested one or two times. In the majority of the plantations the shoots were around 4 years old. In total, 10 different varieties (clones) of Salix were included, which makes the results general and most likely representative for commercial SREFs.

\section{SAMPLING}

The soil and stem wood were analysed regarding, cadmium (Cd), chromium $(\mathrm{Cr})$, copper $(\mathrm{Cu})$, mercury $(\mathrm{Hg})$, nickel $(\mathrm{Ni})$, lead $(\mathrm{Pb})$, tin $(\mathrm{Sn})$ and zinc $(\mathrm{Zn})$. In soil, both the plant available fraction and the total fraction of each metal were analysed. Soil samples were taken within two different levels; $0-30 \mathrm{~cm}$ and $30-60 \mathrm{~cm}$. For both soil and stem biomass the content of dry matter were calculated. At every site three plots, each with an area of approximately $22 \mathrm{~m}^{2}$, were randomly selected. For every plot the growth were calculated and samples were collected for analyses as described above. The results are based on mean values from these three plots at every site.

\section{RESULTS AND DISCUSSION}

\subsection{Sludge}

The chemical composition of the sludge is shown in Table 1. The application rates were overall normal and similar to sludge fertilisation of traditional crops. For some metals the existing limits were exceeded occasionally. However, it should be kept in mind that the sludge were spread when the threshold values were higher than today. 
KALMAR ECO-TECH'03

Bioremediation and Leachate Treatment

KALMAR, SWEDEN, November 25-27, 2003

Table 1. Annual application of sludge, including nutrients and metals.

\begin{tabular}{|c|c|c|c|c|c|c|c|c|c|c|c|c|c|}
\hline & DM & $\mathbf{P}$ & $\mathbf{K}$ & $\begin{array}{c}\text { Tot- } \\
\text { N }\end{array}$ & $\begin{array}{c}\text { NH4- } \\
\text { N }\end{array}$ & Ca & $\mathbf{P b}$ & Cd & $\mathrm{Cu}$ & $\mathrm{Cr}$ & $\mathbf{H g}$ & $\mathbf{N i}$ & $\mathrm{Zn}$ \\
\hline Site & $\mathrm{t} / \mathrm{ha}$ & $\mathrm{kg} / \mathrm{ha}$ & $\mathrm{kg} / \mathrm{ha}$ & $\mathrm{kg} / \mathrm{ha}$ & $\mathrm{kg} / \mathrm{ha}$ & $\mathrm{kg} / \mathrm{ha}$ & $\mathrm{g} / \mathrm{ha}$ & $\mathrm{g} / \mathrm{ha}$ & $\mathrm{g} / \mathrm{ha}$ & $\mathrm{g} / \mathrm{ha}$ & $\mathrm{g} / \mathrm{ha}$ & $\mathrm{g} / \mathrm{ha}$ & $\mathrm{g} / \mathrm{ha}$ \\
\hline Sla & 0,8 & 22 & 4,0 & 41 & 9 & 22 & 69 & 1,3 & 186 & 63 & 0,7 & 17 & 570 \\
\hline Slb & 0,8 & 22 & 4,0 & 41 & 0 & 22 & 69 & 1,3 & 186 & 63 & 0,7 & 17 & 570 \\
\hline S2 & 0,8 & 35 & 1,7 & 43 & 7 & & 38 & 1,3 & 602 & 30 & 1,2 & 17 & 685 \\
\hline S3 & 1,0 & 20 & 4,7 & 58 & 10 & 13 & 10 & 0,5 & 130 & 13 & 0,4 & 10 & 220 \\
\hline S4 & 1,0 & 35 & & 46 & 10 & & 39 & 1,6 & 396 & 20 & 1,7 & 29 & 688 \\
\hline S5 & 0,3 & 9 & 2,7 & 17 & 3 & 7 & 24 & 0,6 & 71 & 11 & 0,3 & 4 & 181 \\
\hline S6a & 0,3 & 9 & 2,7 & 17 & 3 & 7 & 24 & 0,6 & 72 & 11 & 0,3 & 4 & 182 \\
\hline S6b & 0,3 & 9 & 2,7 & 17 & 3 & 7 & 24 & 0,6 & 72 & 11 & 0,3 & 4 & 182 \\
\hline S6c & 0,4 & & & & & & 29 & 0,7 & 106 & 10 & 0,4 & 4,9 & 233 \\
\hline S7 & 0,9 & 28 & 1,8 & 53 & 13 & 16 & 15 & 0,6 & 175 & 17 & 0,7 & 10 & 350 \\
\hline S8 & 0,7 & 20 & & 39 & 7 & & 24 & 0,6 & 306 & 23 & 0,7 & 9 & 445 \\
\hline S9 & 0,8 & 32 & 1,0 & 35 & 7 & & 19 & 0,8 & 497 & 17 & 0,9 & 9 & 442 \\
\hline $\mathrm{S} 10$ & 0,9 & 24 & & 45 & 9 & & 28 & 0,7 & 359 & 27 & 0,8 & 11 & 522 \\
\hline $\mathrm{O} 1^{1}$ & 1,0 & 22 & 1,2 & 36 & 12 & 76 & 31 & 1 & 256 & 17 & 1 & 12 & 362 \\
\hline Ö2 & 0,9 & 22 & 1,2 & 36 & 12 & 75 & 31 & 0,9 & 254 & 17 & 1,0 & 12 & 359 \\
\hline Ö3 & 1,2 & 22 & & 44 & 13 & & 33 & 1,0 & 268 & 18 & 1,0 & 15 & 378 \\
\hline Ö4 & 1,0 & 21 & 1,2 & 36 & 9,7 & & 30 & 0,7 & 234 & 14 & 0,6 & 11 & 390 \\
\hline Ö5 & 1,2 & 26 & 2,1 & 44 & 12 & & 36 & 0,8 & 283 & 17 & 0,7 & 14 & 472 \\
\hline Ö6 ${ }^{1}$ & 1,4 & 22 & 7,3 & 32 & 7,0 & 14 & 41 & 2,2 & 363 & 75 & 0,5 & 34 & 715 \\
\hline Ö7 & 0,9 & 21 & 1,2 & 36 & 9,6 & & 29 & 0,7 & 232 & 14 & 0,6 & 11 & 387 \\
\hline Ö8 & 1,2 & 26 & 2,1 & 44 & 12 & & 36 & 0,8 & 283 & 17 & 0,7 & 14 & 472 \\
\hline Ö9 ${ }^{1}$ & 1,0 & 22 & 1,9 & 37 & 9,9 & & 30 & 0,7 & 239 & 15 & 0,6 & 12 & 398 \\
\hline$\overline{\mathrm{Me}}$ & 0,8 & 23 & 2,4 & 38 & 8,8 & 21 & 32 & 0,8 & 250 & 22 & 0,7 & 12 & 410 \\
\hline
\end{tabular}

Application rate assumed.

\subsection{Soil}

$\mathrm{pH}$ varied between 5 and 6 , which is lower than the mean value for arable land in Sweden, $\mathrm{pH}=6,3$ (Eriksson et al, 1997). A consequence of low $\mathrm{pH}$ is normally that metals are more plant available. Cd together with $\mathrm{Sn}$ showed the highest values of plant available fractions, $21-27 \%$ and $35-37 \%$, respectively. For other metals included in the analyses, the plant available fractions were considerably lower. As an example, the plant available fraction of lead and copper was around $2 \%$ and $5 \%$, respectively. The metal content in the two soil layers did not show any major differences. However, the content of $\mathrm{Cd}, \mathrm{Pb}$ and $\mathrm{Hg}$ was slightly higher in the upper layer, which could be explained by atmospheric deposition during the last century. 


\subsection{Biomass growth}

The average annual biomass production of stems was around $7 \mathrm{t} \mathrm{DM} \mathrm{(dry} \mathrm{matter)/ha}$ (Table 2). For the investigated SREFs in Skane, the southernmost part of Sweden, the growth was $3 \mathrm{t} \mathrm{DM} / \mathrm{ha}$ higher than the growth of the studied SREFs in Örebro, ca $500 \mathrm{~km}$ north of Skåne. This could be explained by the longer growth period in Skåne besides plantations of newer Salix clones with higher biomass production. Extensive breeding programmes towards pest and disease resistance and high-productive clones have resulted in gradually more reliable and higher yields. The average annual production of wood chips from a well-established plantation of willow coppice with shoots $4-6 \mathrm{~m}$ high is in the range of 10-15 t DM/ha and year (Hasselgren, 2003).

Table 2. Biomass production.

\begin{tabular}{|c|c|c|c|c|}
\hline & Shoot age & DM & Growth & Annual average \\
\cline { 2 - 5 } Site $^{1}$ & year & $\%$ & t DM/ha & t DM/ha/y \\
\hline S1a & 4 & 48 & 32,5 & 8,1 \\
\hline S1b & 4 & 46 & 31,4 & 7,8 \\
\hline S2 & 6 & 49 & 43,8 & 7,3 \\
\hline S3 & 1 & 43 & 7,2 & 7,2 \\
\hline S4 & 3 & 42 & $23,0^{2}$ & 7,7 \\
\hline S5 & 3 & 50 & 24,9 & 8,3 \\
\hline S6a & 5 & 50 & 66,1 & 13,2 \\
\hline S6b & 3 & 55 & 30,9 & 10,3 \\
\hline S6c & 1 & 44 & 9,4 & 9,4 \\
\hline S7 & 3 & 48 & 15,1 & 5,0 \\
\hline S8 & 3 & 47 & 24,4 & 8,1 \\
\hline S9 & 2 & 44 & 17,9 & 9,0 \\
\hline S10 & 3 & 43 & 27,6 & 9,2 \\
\hline Ö1 & 8 & 52 & 10,3 & 1,3 \\
\hline Ö2 & 4 & 45 & 27,1 & 6,8 \\
\hline Ö3 & 5 & 51 & 25,7 & 5,1 \\
\hline Ö4 & 5 & 53 & 29,9 & 6,0 \\
\hline Ö5 & 4 & 49 & 19,8 & 4,9 \\
\hline Ö6 & 4 & 51 & 17,4 & 4,3 \\
\hline Ö7 & 5 & 50 & 34,7 & 6,9 \\
\hline Ö8 & 4 & 51 & $25,0^{2}$ & 6,3 \\
\hline Ö9 & 3 & 48 & 17,1 & 5,7 \\
\hline Mean & $\mathbf{4}$ & $\mathbf{4 8}$ & $\mathbf{2 5 , 6}$ & $\mathbf{7 , 2}$ \\
\hline Sin & & & & \\
\hline
\end{tabular}

Sites named "S" are located in Skåne county, sites named "Ö" are located in Örebro county.

${ }^{2}$ Commercial harvest. 


\subsection{Plant uptake of metals}

The results showed a gathered picture of the plant uptake of metals in willow coppice with various conditions, such as root age, soil property and clones. The mean uptake in stem wood is showed in Table 3. Correlations between plant uptake and soil content of metals are not pronounced, except for cadmium. Uptake of $\mathrm{Cd}$ seemed to increase proportionally with the soil content. Especially the Cd content in the subsoil seemed to affect the uptake.

Table 3. Plant uptake in stem wood $(n=22)$.

\begin{tabular}{|c|c|c|c|c|c|c|}
\hline \multirow{2}{*}{ Metal } & \multicolumn{3}{|c|}{$\begin{array}{c}\text { Plant uptake } \\
\text { (mg/kg DM) }\end{array}$} & \multicolumn{3}{c|}{$\begin{array}{c}\text { Areal uptake } \\
\text { (g/ha/y) }\end{array}$} \\
\cline { 2 - 8 } & mean & max & min & mean & max & min \\
\hline $\mathbf{N i}$ & 0,47 & 0,72 & 0,25 & 3,4 & 6,6 & 0,8 \\
\hline $\mathbf{C u}$ & 2,7 & 4,4 & 1,7 & 19 & 40 & 3,4 \\
\hline $\mathbf{Z n}$ & 62 & 94 & 36 & 430 & 850 & 110 \\
\hline $\mathbf{A g}$ & 0,0093 & 0,03 & 0,003 & 0,057 & 0,17 & 0,008 \\
\hline $\mathbf{C d}$ & 1,5 & 2,6 & 0,5 & 10 & 34 & 2,2 \\
\hline $\mathbf{S n}$ & 0,08 & 0,22 & 0,03 & 0,6 & 1,6 & 0,06 \\
\hline $\mathbf{P b}$ & 0,36 & 0,87 & 0,11 & 2,9 & 8,2 & 0,15 \\
\hline $\mathbf{C r}$ & 0,19 & 0,39 & 0,10 & 1,5 & 3,6 & 0,1 \\
\hline
\end{tabular}

\subsection{Comparison with other crops}

As can be seen from data above, utilisation of sewage sludge in SREFs gives a net removal of some metals and accumulation of other metals. Compared with other crops the general pattern is that the uptake and removal of metals from soil is higher with Salix. This is exemplified by $\mathrm{Cd}$ in Table 4 and for some other metals in Table 5. Copper is an exception.

The plant uptake varies for both Salix and other crops but the potential of achieving a net removal or at least a decreased accumulation is higher for Salix compared with other crops. 
KALMAR ECO-TECH'03

Bioremediation and Leachate Treatment

KALMAR, SWEDEN, November 25-27, 2003

Table 4. Uptake of cadmium in Salix stems and 7 other common crops.

\begin{tabular}{|l|c|c|c|}
\hline Crop & $\begin{array}{c}\text { Concentration } \\
\mathrm{mg} / \mathrm{kg} \text { DS }\end{array}$ & $\begin{array}{c}\text { Uptake } \\
\mathrm{g} / \mathrm{ha} / \mathrm{y}\end{array}$ & $\begin{array}{c}\text { Relative uptake } \\
\text { Salix = Index 100 }\end{array}$ \\
\hline $\begin{array}{l}\text { Salix } \\
\text { Winter }\end{array}$ & 1,5 & 10 & 100 \\
wheat $^{1}$ & 0,044 & 0,23 & 2,3 \\
Oats $^{1}$ & 0,036 & 0,13 & 1,3 \\
Spring $^{\text {Sparley }}$ & & & \\
Triticalea & 0,019 & 0,065 & 0,7 \\
Potatoea & 0,046 & 0,23 & 2,3 \\
Oil seed $^{\text {Rape }}{ }^{1}$ & 0,053 & 0,47 & 4,7 \\
Carrot $^{1}$ & 0,082 & 0,21 & 2,1 \\
\hline
\end{tabular}

${ }^{\mathrm{T}}$ Source: Johannesson and Nielsen (2003)

Table 5. Uptake of metals in Salix stems compared with wheat.

\begin{tabular}{|c|c|c|c|}
\hline \multirow{2}{*}{ Metal } & \multicolumn{2}{|c|}{$\begin{array}{c}\text { Uptake } \\
\mathrm{g} / \text { ha/y }\end{array}$} & Relative uptake \\
& Salix/Wheat \\
\cline { 2 - 3 } & Salix & Wheat $^{{ }^{1}}$ & 3,4 \\
$\mathrm{Ni}$ & 3,4 & 1 & 0,69 \\
$\mathrm{Cu}$ & 19 & 28 & 2,7 \\
$\mathrm{Zn}$ & 430 & 160 & $>20$ \\
$\mathrm{Ag}$ & 0,057 & $<0,003$ & 49 \\
$\mathrm{Cd}$ & 10 & 0,21 & 1,2 \\
$\mathrm{Sn}$ & 0,58 & 0,5 & 59 \\
$\mathrm{~Pb}$ & 2,6 & 0,044 & 23 \\
$\mathrm{Cr}$ & 1,5 & 0,066 & \\
\hline
\end{tabular}

Source: Eriksson (2001)

\section{METAL BALANCES}

Considering metal balances, several factors must be taken into consideration. The metal flow to and from the soil, for instance, is influenced by soil characteristics, fertilisers and atomspheric deposition. Furthermore, metals are reallocated from the subsoil to the topsoil. The reallocation is mainly caused by a contribution of metals from dead leaves, but also from the roots. (Perttu et al, 2002).

The depth of the root systems depends on factors such as the supply of nutrients and water and the soil structure. If the supply of water and nutrient is sufficient the roots do not tend to go deep. This affects the total removal of metals from the topsoil due to an increased uptake from the topsoil and decreased reallocation of metals from the subsoil to the topsoil. 


\section{GENERAL INFORMATION ABOUT THE LAPES LANDFILL IN KAUNAS}

Household and industrial waste from Kaunas City is presently disposed at Lapes Landfill situated approximately $13 \mathrm{~km}$ north - east the city center and in operation since 1973 . Landfill serves more than 600000 population. The landfill is set up in a natural hollow. The whole area of landfill takes 38.7 ha. Household waste takes up the area of only 12.5 ha. The average height of waste hill is $20 \mathrm{~m}$. After thirty-year exploitation, about $2.5 \mathrm{mln}$. $\mathrm{m}^{3}$ of waste is already collected. Every year the landfills increase by 100-130 thousand tons of waste. But only about $1-2 \%$ of collected and transported waste to landfill is recycled (see figure 1).

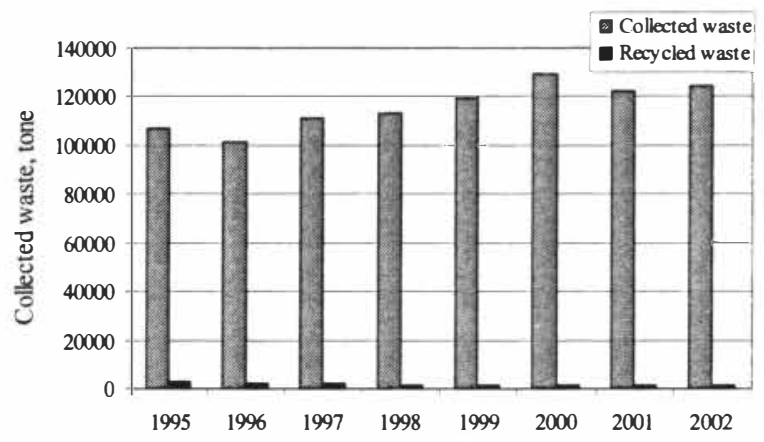

Figure 1. Volume of collected and recycled waste

Typical composition of waste is presented in figure 2. Household waste (organic), paper, cardboard, plastic and other flammable materials dominate there.

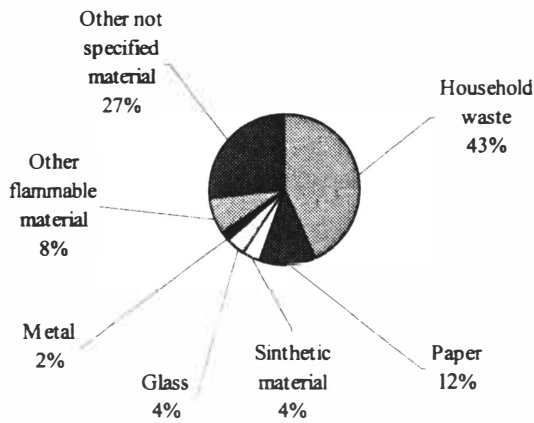

Figure 2. Composition of waste at Lapes Landfill 

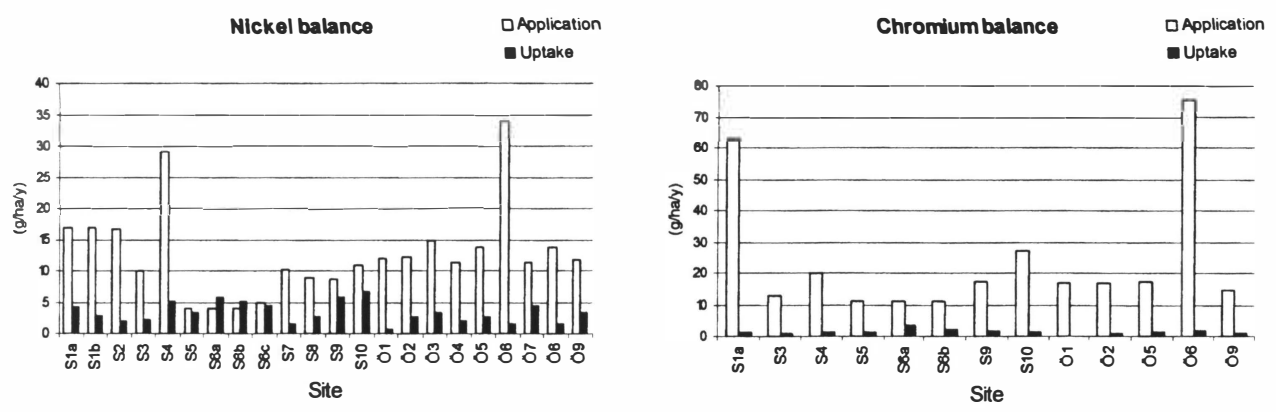

Figure 1. Relations between supplied amounts from sludge and uptake in stem wood concerning cadmium, copper, lead, zinc, nickel and chromium

The Cd content in the topsoil will according to this reasoning decrease with around 4,5 $\mathrm{g} / \mathrm{ha} / \mathrm{y}$ as a mean value for the studied SREF. Besides this the cadmium content in the subsoil will decrease with $4,5 \mathrm{~g} / \mathrm{ha} / \mathrm{y}$, which gives a total cadmium reduction in the soil of $9 \mathrm{~g} / \mathrm{ha} / \mathrm{y}$. With these calculations would the total fraction of plant available cadmium in the topsoil be more than halved after 25 years.

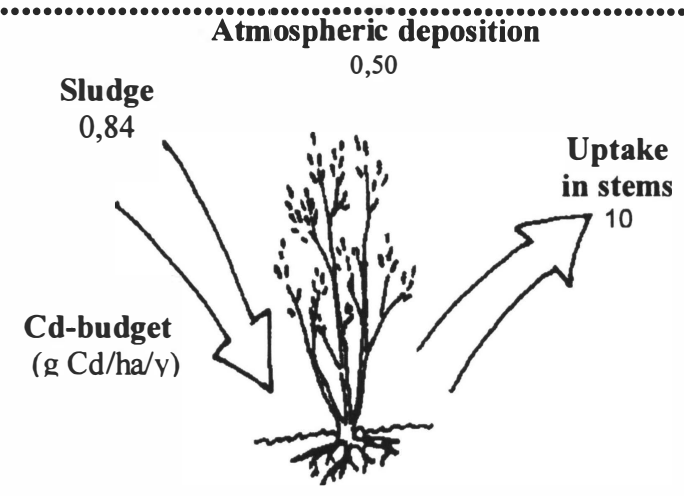

Figure 2. Input and output of cadmium for investigated SREF.s. The concentrations are mean values. 
Relative to the total amount of $\mathrm{Cd}$ in the topsoil the decrease would be $14 \%$. This amount (approximately $100 \mathrm{~g} / \mathrm{ha}$ ) is in the same range as the supply of Cd from fertilisers and atmospheric deposition to Swedish farming land during the last century ( $\AA$ byhammar, 1993).

The same calculations as described above were also conducted for $\mathrm{Pb}$ and $\mathrm{Cu}$. The general conclusion was that there would be a net accumulation of these metals in the topsoil with sludge fertilised willow coppice. However, the percentage accumulation in relation to existing levels in the topsoil is very small. It is estimated that the $\mathrm{Pb}$ content in the topsoil would increase with $2 \%$ after 25 years of sludge fertilisation. For $\mathrm{Cu}$ it is expected that the accumulation would be higher. The $\mathrm{Cu}$ content in the topsoil would increase annually with around $0,4 \%$. Still, for both $\mathrm{Cu}$ and $\mathrm{Pb}$ the relative accumulation in the topsoil and the subsoil together, would be considerably smaller than in the topsoil.

\section{POTENTIALS}

One way to show the potential of Salix for phytoremediation can be to present the amount of sludge which is needed to balance the uptake of each metal in willow stems (Table 6). With sludge quality according to the latest published statistics (SCB, 2002) and with uptake in stems of the studied SREFs it is possible to apply between 9 and 10 t DS sludge/ha/y to a plantation without achieving accumulation of $\mathrm{Cd}$ in the soil. The metals that can be removed via the stems to smallest extent are $\mathrm{Cu}$ and $\mathrm{Pb}$ followed by $\mathrm{Ni}$ and $\mathrm{Zn}$.

Table 6. Amount of sludge in order to balance the uptake in stem wood. The concentration of each metal is according to statistics of Swedish sewage sludge.

\begin{tabular}{|c|ccccc|}
\hline Metal & $\begin{array}{c}\mathbf{A} \\
\mathrm{mg} / \mathrm{kg} \mathrm{DM}\end{array}$ & $\begin{array}{c}\mathbf{B} \\
\mathrm{mg} / \mathrm{kg} \mathrm{DM}\end{array}$ & $\begin{array}{c}\mathbf{C} \\
\mathrm{g} / \mathrm{ha} / \mathrm{y}\end{array}$ & $\begin{array}{c}\mathbf{D} \\
\mathrm{kg} \mathrm{DM} / \mathrm{ha} / \mathrm{y}\end{array}$ & $\begin{array}{c}\mathbf{E} \\
\mathrm{kg}\end{array} \mathbf{\mathrm { ha }} / \mathrm{y}$ \\
\hline $\mathrm{Pb}$ & 34 & 29 & 2,9 & 85 & 98 \\
$\mathrm{Cd}$ & 1,1 & 0,9 & 10 & 9400 & 11000 \\
$\mathrm{Cu}$ & 370 & 280 & 19 & 52 & 70 \\
$\mathrm{Ni}$ & 17 & 12 & 3,4 & 200 & 270 \\
$\mathrm{Zn}$ & 550 & 460 & 430 & 780 & 940 \\
\hline
\end{tabular}

Explanations:

A: Mean values in sludge from municipal wastewater treatment plants in Sweden (SCB, 2002).

B: Mean values in sludge from municipal wastewater treatment plants in Sweden with p.e. $<20000$ (SCB, 2002).

C: Mean uptake of each metal in the measured SREFs.

D: Amount of applied sludge when uptake of each metale supplied amount of the metal with sludge (column A).

E: Amount of applied sludge when uptake of each metale supplied amount of the metal with sludge (column B). 
KALMAR ECO-TECH'03

Bioremediation and Leachate Treatment

KALMAR, SWEDEN, November 25-27, 2003

Several studies have shown on differences in metal uptake between different Salix clones (Greger and Landberg, 1999). Even though some of the indications still are not established, it is estimated that there is a potential to refine Salix towards a selective uptake pattern. For instance, it is reported from field studies of 88 different Salix clones the following maximum concentrations of metals in stems; $56 \mathrm{mg} \mathrm{Cd} / \mathrm{kg} \mathrm{DM}, 18 \mathrm{mg}$ $\mathrm{Pb} / \mathrm{kg} \mathrm{DM}, 12 \mathrm{mg} \mathrm{Cu} / \mathrm{kg} \mathrm{DM}, 230 \mathrm{mg} \mathrm{Zn/kg} \mathrm{DM}$ and $8 \mathrm{mg} \mathrm{Sn} / \mathrm{kg}$ DM (Bertholdsson, 2001). These results show considerably higher metal extraction rates compared with the commercial clones investigated in this study.

Consequently it can be expected that the ongoing work towards Salix clones with higher biomass production and metal uptake can lead to commercial clones, which can provide a sustainable net removal of more metals than reported in this study.

Traditionally, a major part of the Swedish production of biosolids has been recycled in the agriculture. Today almost no sludge is received by the farmers due to the general uncertainty about the sludge quality and the effect on soil and food crops, especially considering the metal aspect. Biosolids in Sweden contain relatively high amounts of phosphorus (chemical precipitation of $\mathrm{P}$ ) compared with other nutrients in the sludge. If the application of $\mathrm{P}$ with biosolids were balanced with the $\mathrm{P}$ requirement of the plants, the amount of other nutrients, especially $\mathrm{K}$, supplied with biosolids would be below the plant need (Hasselgren, 1999). Normally, sewage sludge ought to be recognised primarily as a $\mathrm{P}$ source to provide for the long-term crop need while $\mathrm{N}$ and $\mathrm{K}$ has to be added from other sources.

Sludge from the Swedish wastewater treatment plants can potentially supply the future willow-to-energy plantations (100 000's of hectares) in the country with full amounts of phosphorus and with parts of the other nutrient requirement. Further, application of biosolids increases the content of organic matter in the soil.

Other identified environmental and general benefits of growing willows for energy purposes are the possibilities to achieve increased soil carbon accumulation and the function as shelter belts against soil erosion (Börjesson et al, 2002). In the 1980's when willow biomass plantations was introduced on a large scale in Sweden, the public acceptance considering the appearance of a new crop in the landscape became a question of concern. Studies on this resulted in suggestions such as restrictions of planting too close to roads to avoid screening of scenic views, location of the crop to lower parts of the landscape, allowing corners to be rounded and edges to be curved, and allowing other species in the fringes (Perttu, 1998). These aspects have been taken into consideration and new plantations are left with very few comments. The most common opinion today is that Salix plantations are an exciting new feature of the landscape (Skärbäck, 2002).

\section{CONCLUSIONS}

Based on the studies of metal uptake in commercial short rotation energy forests fertilized with sewage sludge the following conclusions could be drawn. 
- The uptake rate of the investigated metals was in general higher than for conventional agricultural crops. Consequently, an increased acreage of short-rotation energy forestry in expense of traditional crops results in decreased accumulation of metals of arable land.

- The uptake of $\mathrm{Cd}$ in willow stems clearly exceeded (around 10 times) the application of Cd with sewage sludge (normal sludge application rates). Even when atmospheric deposition and reallocation of cadmium from subsoil to topsoil were included, a net removal from the topsoil was calculated (4-5 g Cd/ha/year). This means that willow coppice can act as a treatment filter for $\mathrm{Cd}$ contaminated agricultural land in combination with recovery of resources (nutrients and organic matter) from sewage sludge.

- The uptake of $\mathrm{Zn}$ was balanced with the application of $\mathrm{Zn}$ via sewage sludge, while other metals were accumulated in the soil. The investigated plantations were around 10 years old and planted with old Salix clones. The ongoing work finding clones with higher biomass production and metal uptake rates will lead to a more effective metal removal

- The biomass production (willow stem growth) after fertilisation with municipal sewage sludge showed to be at the same level or higher compared with conventionally cultivated willow biomass plantations in Sweden.

- Generally, an increased acreage of willow biomass plantations in Europe could contribute to less over-production of conventional agricultural crops, less greenhouse gas emissions and less use of fossil fuel resources.

\section{REFERENCES}

[1] Alvén, B., Eriksson, L., Persson, S. and Hasselgren, K. (2003). Salix as a metal remediator - an exciting challenge (Salix som metallsanerare - en spännande utmaning). Svenskt Vatten, No. 1/2003e32-33. In Swedish.

[2] Bertholdsson, N-O. (2001). Phytoremediation of heavy metals with Salix (Fytoremediering av tungmetaller med hjälp av Salix). J. Swed. Seed Assoc., No. 2/2001: 84-90. In Swedish, English summary.

[3] Börjesson, P., Berndes G., Fredriksson, F. and Kåberger, T. (2002). Multi-functional bioenergy plantations (Multi-funktionella bioenergiodlingar). Report EO-02/4, National Swedish Energy Agency, Eskilstuna, Sweden. In Swedish, English summary.

[4] Eriksson, J. (2001). Concentrations of 61 trace elements in sewage sludge, stable manure, manufactured fertilisers, precipitation, soil and crops (Halter av 61 spårelement $i$ avloppsslam, stallgödsel, handelsgödsel, nederbörd samt i jord och gröda). Report 5148, National Swedish Environmental Protection Agency, Stockholm, Sweden. In Swedish, English summary. 
KALMAR ECO-TECH'03

Bioremediation and Leachate Treatment

KALMAR, SWEDEN, November 25-27, 2003

[5] Greger, M and Landberg, T (1999). Use of willow in phytoextraction. Int. J.

Phytorem. 1(2):115-124.

[6] Hasselgren, K. (1999). Utilization of sewage sludge in short-rotation energy forestryaa pilot study. Waste Management \& Research, 17: 251-262.

[7] Hasselgren, K. (2003). Use and treatment of municipal waste products in willow biomass plantations. Report No. 3242. Department of Water Resources Engineering, Lund Institute of Technology/Lund University, Lund, Sweden.

[8] Johannesson, M. and Nielsen, B. (2003). Valuation of the possibility to remediate Swedish agricultural land from cadmium with Salix (Värdering av möjligheten att rena svensk åkermark från kadmium med hjälp av Salix). ER 11:2003, the National Swedish Energy Agency, Eskilstuna, Sweden. In Swedish, English summary.

[9] Perttu, K. (1998). Environmental justification for short-rotation forestry in Sweden. Biomass and Bioenergy, 15(1), 1-6.

[10] Perttu, K., Eriksson, J., Greger, M., Blombäck, K., Klang-Westin, E. and Landberg, T. (2002). Supply and flow of cadmium in the system soil and Salix (Förråd och flöden av kadmium i systemet mark-Salix). Swedish University of Agricultural Sciences, Uppsala, Sweden. In Swedish, English summary. To be published.

[11] SCB (2002). Discharges to water and sludge production year 2000 (Utsläpp till vatten och slamproduktion 2000). MI 22 SM 0101, Statistics Sweden. In Swedish, English summary

[12] Skärbäck, E. (2002). Energy forests - more than energy. Proceedings IEA Bioenergy Workshop, 28 October -1 November, 2002, Bello Horisonte, Brazil. To be published in Biomass and Bioenergy.

[13] Åbyhammar, T., Fahlin, M. and Holmroos, S. (1993). Cadmium in the biofuel system (Kadmium i biobränslesystemet). Report UB 1993/13, Vattenfall Utveckling, Stockholm, Sweden. In Swedish, English summary.

\section{ACKNOWLEDGEMENTS}

The Municipalities of Landskrona, Helsingborg and Örebro, the Research Foundation of the Swedish Water and Wastewater Association and NSR AB, are all acknowledged for their financial support of the project, of which results are referred to in this paper. Furthermore are all of the farmers who made this study possible acknowledged as well as Agrobränsle $\mathrm{AB}$ and The Swedish Rural Economy and Agricultural Society. 